\title{
KADAR SERAT PANGAN DAN SIFAT ORGANOLEPTIK CRACKERS BEKATUL JAGUNG DENGAN PENAMBAHAN TEPUNG KACANG BAMBARA
}

\author{
(Dietary Fiber and Organoleptic of Corn Bran Crackers with Addition of \\ Bambara Groundnut Flour)
}

\author{
Panji Octo Prasetio ${ }^{a^{*}}$, Ikha Deviyanti Puspitaa ${ }^{a}$ lin Fatmawatia \\ a Fakultas IImu Kesehatan, Universitas Pembangunan Nasional Veteran Jakarta, Indonesia \\ * Penulis koresponden: \\ Email: panjioctoprasetio@upnvi.ac.id
}

\begin{abstract}
Low-fiber diet is one of the risks that can lead to obesity. According to RISKESDAS in 2018 the prevalence of obesity at> 18 years of age increases to $21.8 \%$. World Health Organization recommends adequate fiber consumption from 25-30 g/day according to age. In actual fact, Indonesian people's fiber intake is on average 10.5g/day. Local foods that have high fiber are corn bran and bambara groundnuts. The materials used in this study were corn bran, wheat flour, margarine and eggs. This study used an experimental research design with a completely randomized design with two repetitions. The formula is divided into 4 , with each level of ratio of corn bran with the addition of bambara bean flour of FO (100\%:0\%), F1 (80\%:20\%), F2 (70\%:30), and F3 (60\%:40). The results of the analysis of the organoleptic test, the addition of bambara bean flour had a significant effect $(p<0.05)$ on the level of preference for the panelists on the color attribute and on the proximate test and levels of food fiber, the addition of bambara bean flour had a significant effect $(p<0.05)$ on protein content and levels. dietary fiber crackers. Formula 3 is the selected formula which has moisture content (7.99\%), ash content (2.43\%), carbohydrate content (51.61\%), fat content (26.9\%), protein content (11.06\%). ) and food fiber content (21.17\%).
\end{abstract}

Keywords: bambara groundnut, corn bran, crackers, dietary fiber

\begin{abstract}
ABSTRAK
Salah satu penyebab obesitas adalah kebiasaan mengkonsumsi makanan rendah serat. Menurut RISKESDAS tahun 2018 prevalensi obesitas pada usia $>18$ tahun meningkat menjadi $21,8 \%$. World Health Organization menganjurkan konsumsi serat yang cukup berkisar 25-30 gram/hari sesuai dengan umur. Pada penerapan sebenarnya asupan serat masyarakat Indonesia rata-rata 10,5g/hari. Pangan lokal yang memiliki kadar serat yang tinggi adalah bekatul jagung dan kacang bambara. Bahan yang digunakan dalam penelitian ini adalah bekatul jagung, tepung terigu, margarin dan telur ayam. Penelitian ini menggunakan desain penelitian eksperimental dengan Rancangan Acak Lengkap dengan dua pengulangan. Formula dibedakan menjadi 4 dengan masing-masing tingkat perbandingan bekatul jagung dengan penambahan tepung kacang bambara sebesar F0 (100\%:0), F1 (80\%:20\&), F2 (70\%:30), dan F3 (60\%:40\%). Hasil analisis uji organoleptik penambahan tepung kacang bambara berpengaruh nyata $(p<0,05)$ pada tingkat kesukaan panelis pada atribut warna dan pada uji proksimat dan kadar serat pangan penambahan tepung kacang bambara berpengaruh nyata $(p<0,05)$ terhadap kadar protein dan kadar serat pangan crackers. Formula 3 merupakan formula terpilih yang memiliki kadar air (7,99\%), kadar abu $(2,43 \%)$, kadar karbohidrat $(51,61 \%)$, kadar lemak $(26,9 \%)$, kadar protein $(11,06 \%)$ dan kadar serat pangan $(21,17 \%)$.
\end{abstract}

Kata kunci: bekatul jagung, crackers, kacang bambara, serat pangan 


\section{PENDAHULUAN}

Serat pangan atau biasa dikenal dengan serat diet atau dietary fiber (DF) adalah karbohidrat kompleks dimana merupakan bagian dinding sel tanaman pangan yang sulit diuraikan oleh enzim dan sulit diserap oleh saluran pencernaan. Serat pangan memiliki fungsi penting untuk memelihara kesehatan manusia, mencegah penyakit dan sebagai komponen penting dalam diet (Rahmah, Rezal \& Rasma 2017). Serat pangan dapat diklasifikasikan menjadi dua kelompok atas dasar sifat kelarutan. Kelompok serat yang dapat larut air yaitu, pektin, gom, dan $\beta$-glukan; selain itu ada juga kelompok serat pangan yang tidak larut air, seperti selulosa, lignin, dan hemiselulosa (Dhingra et al., 2012). Serat pangan larut air sering dihubungkan dengan penurunan kadar kolesterol dalam darah dan penurunan absorbsi glukosa di usus, sementara serat pangan tidak larut air biasa dikaitkan dengan proses penyerapan air dan pengaruh regulasi dalam usus (Rantika \& Rusdiana, 2018).

World Health Organization menganjurkan konsumsi serat yang cukup berkisar 25-30 g/hari sesuai dengan umur. Asupan serat harian berdasarkan pada Angka Kecukupan Gizi (AKG) yang dianjurkan untuk masyarakat Indonesia antara $29 \mathrm{~g}$ sampai dengan $37 \mathrm{~g}$ sesuai dengan kelompok umur dan jenis kelamin (Kemenkes RI, 2018). Pada penerapan sebenarnya asupan serat masyarakat Indonesia rata-rata 10,5g/hari (Rahmah, Rezal \& Rasma 2017) . Perubahan kebiasaan konsumsi di Indonesia menyebabkan konsumsi sayuran dan buah yang berkurang (Maryusman et al., 2018). Pola makan rendah serat menjadi salah satu resiko yang dapat menyebabkan terjadinya obesitas dan DCS (Disease of Circulatory System) (Maryusman et al., 2018). Obesitas terjadi karena konsumsi energi yang berlebih ke dalam tubuh, dan disimpan dalam bentuk jaringan lemak (Fatmawati, Pradhan \& Arini 2020).
Dalam menjaga kesehatan, serat pangan berfungsi mengontrol berat badan dari kegemukan (obesitas), penanggulangan penyakit diabetes, mencegah penyakit gastrointestinal dan kanker kolon, serta mengurangi tingkat kolesterol dalam darah sehingga mencegah penyakit kardiovaskuler (Santoso, 2011). Dalam pengetahuan gizi, serat biasa disamakan dengan yang ada pada sayur-sayuran dan buah-buahan atau yang dikenal dengan dengan sebutan serat kasar, namun serat pada makanan tidak hanya terdapat pada sayuran dan buahbuahan, namun juga terdapat pada makanan lain seperti umbi-umbian, serealia dan produk sampingannya serta kacangkacangan (Kusharto, 2007).

Bekatul jagung merupakan produk sampingan dalam industri penggilingan sereal, yang secara tradisional digunakan dalam pakan ternak. Bekatul jagung mengandung serat pangan yang tinggi sekitar 76-90\% (Singh, Liu \& Vaughn 2012). Serat pangan pada bekatul jagung sebagian besar tidak larut sama sekali oleh air itu merupakan struktur penyusun utama bekatul jagung. Serat pangan tidak larut air dari bekatul jagung terdiri dari selulosa (200$280 \mathrm{~g} / \mathrm{kg}$ ), hemiselulosa $(700 \mathrm{~g} / \mathrm{kg})$, dan lignin $(10 \mathrm{~g} / \mathrm{kg})$ (Dapčević-Hadnađev, Hadnađev \& Pojić 2018). Karena bekatul jagung tersedia dengan harga murah dan kaya serat maka dapat dicoba sebagai alternatif pembuatan produk pangan kaya serat untuk memberi nilai tambah (Parate, Kale and Talib, 2019).

Kacang bambara biasa dikenal sebagai kacang bogor di Indonesia dan banyak diolah menjadi produk makanan seperti kacang rebus dan kacang goreng (Ramadhani, 2017). Kacang bambara dilaporkan memiliki konsentrasi serat larut air tertinggi di antara kacang-kacangan lainnya. Serat larut adalah non-gizi yang diyakini dapat mengurangi kejadian penyakit jantung dan mencegah kanker usus besar (Murevanhema and Jideani, 2013). Kacang bambara mengandung $20,6 \%$ protein, $6,6 \%$ lemak, $6,3 \%$ serat, $3,25 \%$ abu, dan $56,61 \%$ karbohidrat dalam 100 gram bahan (Adhi, 2018 dalam Rahayu et. al., 2020). Kacang 
bambara bisa dijadikan tepung karena mengandung kadar karbohidrat yang tinggi. Tepung kacang Bambara dapat digunakan sebagai pengganti pembuatan kue. Penggunaan tepung kacang Bambara dapat mengurangi kebutuhan tepung dan penambah rasa dalam pembuatan cookies (Rahayu, Destiana \& Fathurohman 2020).

Crackers adalah kategori makanan ringan terbesar di antara produk yang diolah dengan cara dipanggang. Crackers merupakan sarana termudah untuk menjangkau seluruh lapisan masyarakat karena kemudahan konsumsi, biaya produksi yang rendah, dan pola konsumsi yang luas (Olagunju et al., 2018). Menurut data statistik Kementerian Perindustrian Indonesia, lonjakan permintaan impor serealia pada tahun 2016 meningkat pada tahun 2018 merupakan cerminan peningkatan konsumsi masyarakat, salah satunya terhadap produk biskuit (Portal Statistik Perdagangan 2019). Selain itu menurut Kementerian Pertanian, 2018 dalam Statistik Konsumsi Pangan Tahun 2018 menunjukkan bahwa rata-rata konsumsi per kapita produk biskuit termasuk crackers sebesar $2.282 \mathrm{~kg}$ per tahun, meningkat $208 \mathrm{~kg}$ dari tahun sebelumnya. Diperkirakan sampai tahun 2020 juga terjadi peningkatan rata-rata konsumsi per kapita per tahun (Kementerian Pertanian, 2018). Tujuan dari penelitian ini adalah menganalisis pengaruh kandungan proksimat, serat pangan dan hasil uji organoleptik pada crackers bekatul jagung dengan penambahan tepung kacang bambara.

\section{Bahan}

\section{BAHAN DAN METODE}

Bahan baku yang digunakan dalam pembuatan crackers adalah kacang bambara, bekatul jagung, tepung terigu, margarin, telur ayam. Bahan uji protein (K2SO4, HgO, H2SO4, $\mathrm{NaOH}-\mathrm{Na} 2 \mathrm{~S} 2 \mathrm{O} 3$, $\mathrm{H} 3 \mathrm{BO} 3$ dan $\mathrm{HCl}$ ), uji lemak $(\mathrm{HCl}$ dan hexana), kadar serat pangan (termamyl, bufer fosfat, $\mathrm{NaOH}, \mathrm{HCl} 0,325 \mathrm{~N}$, dan AMG), dan untuk uji organoleptik menggunakan produk crackers bekatul jagung yang sudah dibuat dan air mineral.

\section{Preparasi Bahan}

Kacang bambara dibersihkan dari tanah kemudian direndam dalam air selama 24 jam. Kemudian kacang bambara direbus selama 5 menit agar mudah dikupas.

\section{Pembuatan Tepung Kacang Bambara}

Pembuatan tepung kacang bambara mengacu pada penelitian (Abdualrahman et al., 2012) dan (Yusufu \& Ejeh, 2018) yang sudah di modifikasi. Kacang bambara yang sudah dikupas kemudian dikeringkan dengan oven pengering pada suhu $500 \mathrm{C}$ selama 9 jam. Setelah kering kemudian kacang digiling menjadi tepung halus kemudian tepung tersebut melewati ayakan 80 mesh. Tepung disimpan dalam wadah kering pada suhu kamar (320C) sebelum diolah menjadi tambahan adonan crackers.

\section{Metode pengolahan}

Metode pengolahan pada penelitian ini adalah dipanggang. Pembuatan crackers bekatul jagung dengan penambahan tepung kacang bambara mengacu pada penelitian (Setyowati and Nisa, 2014) dan (Adegbanke, Ojo-uyi \& Oluwajuyitan 2019) dengan modifikasi. Pertama siapkan bahan-bahan, gula halus ditimbang sebanyak $30 \mathrm{~g}$, margarin sebanyak $100 \mathrm{~g}$. Margarin, gula, dan telur dicampur menggunakan mixer kecepatan rendah \pm 10 menit (pencampuran I). Ditambahkan bekatul jagung dan tepung terigu yang selanjutnya akan disubtitusi dengan tepung kacang bambara sesuai masing-masing konsentrasi (20\%:80\%; 30\%:70\%; 40\%:60\%). Lalu campur menggunakan mixer dengan kecepatan medium selama \pm 3 menit (Pencampuran II). Adonan yang diperoleh kemudian dicetak dengan ukuran tebal $0,5 \mathrm{~cm}$; bentuk persegi $4 \times 7 \mathrm{~cm}$. Siapkan loyang yang telah diolesi dengan mentega, susun adonan yang sudah di cetak pada loyang kemudian panggang di oven pada suhu $160^{\circ} \mathrm{C}$ selama \pm 20 menit, setelah matang simpan di tempat kering dan tertutup. 


\section{Analisis Statistik}

Data pada penelitian ini dilaporkan dalam bentuk median, rata-rata \pm standar deviasi. Data hasil uji analisis proksimat dan uji kadar serat akan dianalisis secara statistik menggunakan uji ANOVA. (analysis of variance), jika ada perbedaan $(p<0,05)$, dilanjutkan menggunakan uji Duncan. Data hasil uji hedonik dianalisis menggunakan uji Kruskall Wallis. Apabila data yang berbeda nyata $(\alpha<0,05)$, maka dilanjutkan dengan uji Mann-Whitney. Penentuan formulasi terpilih dengan metode perbandingan eksponensial (MPE) yang merupakan teknik pengambilan keputusan dalam menentukan ranking dari beberapa alternatif keputusan berdasarkan beberapa kriteria keputusan.

\section{HASIL DAN PEMBAHASAN Sifat Organoleptik}

Pengujian sifat organoleptik dilakukan untuk mengetahui penilaian panelis terhadap masing-masing aspek pada produk crackers sebagai bahan penguji (Noviyanti et al., 2016). Pengujian ini menggunakan uji hedonik atau uji kesukaan terhadap atribut warna, aroma, tekstur dan rasa. Pada peneltian ini uji hedonik menggunaka skala satu sampai lima dengan klasifikasi (1) sangat tidak suka, (2) tidak suka, (3) biasa saja, (4) suka, (5) sangat suka.

\section{Warna}

Hasil analisis Kruskall Wallis menunjukkan tingkat penambahan tepung kacang bambara berpengaruh nyata $(p=0,001)$ terhadap tingkat kesukaan panelis pada paramerter warna crackers. Hasil uji lanjut Mann-Withney menunjukkan bahwa nilai median tingkat kesukaan warna crackers F0 berbeda nyata $(p=0,015)$ dibandingkan dengan crackers $\mathrm{F} 1$, crackers F0 berbeda nyata $(p=0,003)$ dibandingkan dengan crackers F2, crackers F0 berbeda nyata $(p=0,001)$ dibandingkan dengan crackers F3. Nilai median kesukaan warna crackers $F 1$ tidak berbeda nyata $(p=0,309)$ dengan crackers F2, crackers F1 tidak berbeda nyata $(p=0,059)$ dengan crackers
F3, dan juga median kesukaan warna crackers F2 tidak berbeda nyata $(p=0,349)$ dengan crackers F3. Hal ini terjadi karena adanya perubahan warna yang terjadi akibat dari penambahan tepung kacang bambara yang memiliki warna yang lebih gelap sehingga warna crackers F0 akan terlihat lebih cerah dibandingkan dengan crackers F1, F2, dan F3.

Penelitian Nyau et al., 2015 menunjukkan kacang bambara mengandung senyawa polifenol, utamanya dari kelas flavonoid. Senyawa fenolik ini mengakibatkan adanya reaksi browning enzimatik yang disebabkan adanya reaksi antara substrat fenolik dan oksigen dengan katalisator polifenol oksidase (Chandra et al., 2013). Selain itu penggelapan warna juga dapat terjadi karena selama proses pemanggangan terjadi reaksi karamelisasi dan reaksi Maillard (Adegbanke, Osundahunsi, et al., 2019).

\section{Aroma}

Berdasarkan pada analisis Kruskall Wallis menunjukkan bahwa tingkat penambahan tepung kacang bambara tidak berpengaruh nyata $(p=0,718)$ terhadap tingkat kesukaan panelis. Crackers F0, F1, F2 dan F3 memiliki aroma gurih namun langu khas bekatul. Aroma dari tepung kacang bambara yang kurang kuat sehingga tidak ada perbedaan aroma yang bermakna (Adegbanke, Ojo-uyi, et al., 2019).

Pada crackers sampel aroma bekatul jagung sedikit langu sehingga menimbulkan aroma yang menyengat dan dominan, hal itu ditimbulkan dari komponen volatile (tokoferol) pada bekatul (Kusumastuty et al., 2015). Penggunaan margarine pada formula juga meningkatkan nilai aroma gurih pada produk (Widiantara, 2018).

\section{Tekstur}

Tingkat penambahan tepung kacang bambara tidak berpengaruh nyata $(p=0,747)$ terhadap tingkat kesukaan panelis pada parameter tekstur. Hal ini dikarenakan perbandingan kadar protein dan lemak pada 
Tabel 1. Hasil Uji Hedonik Crackers Bekatul Jagung dengan Penambahan Tepung Kacang Bambara

\begin{tabular}{ccccc}
\hline \multirow{2}{*}{ Parameter } & \multicolumn{4}{c}{ Nilai median uji hedonik crackers bekatul jagung dengan } \\
\cline { 2 - 5 } & $\mathrm{F} 0$ & $\mathrm{~F} 1$ & $\mathrm{~F} 2$ & $\mathrm{~F} 3$ \\
\cline { 2 - 5 } penambahan tepung kacang bambara & $4^{\mathrm{b}}$ & $3^{\mathrm{b}}$ & $3^{\mathrm{b}}$ \\
Warna & $4^{\mathrm{a}}$ & $3^{\mathrm{a}}$ & $3^{\mathrm{a}}$ & $3^{\mathrm{a}}$ \\
Tekstur & $3,5^{\mathrm{a}}$ & $3^{\mathrm{a}}$ & $3^{\mathrm{a}}$ & $4^{\mathrm{a}}$ \\
Rasa & $3,5^{\mathrm{a}}$ & $3^{\mathrm{a}}$ & $3^{\mathrm{a}}$ & $3^{\mathrm{a}}$ \\
\hline
\end{tabular}

Keterangan: Perbandingan bekatul jagung dengan tepung kacang bambara F0 (100:0) F1 (80:20), F2 (70:30) dan F3 (60:40). a, b, c, dan d = angka-angka pada baris yang sama kemudian diikuti oleh notasi huruf yang sama berarti tidak berbeda nyata pada taraf uji Kruskal Wallis

Tabel 2. Kandungan Proksimat Crackers Bekatul Jagung dengan Penambahan Tepung Kacang Bambara

\begin{tabular}{|c|c|c|c|c|c|c|}
\hline \multirow{2}{*}{ Komponen } & \multicolumn{4}{|c|}{ Sampel } & \multirow{2}{*}{$\begin{array}{c}\text { SNI } \\
\text { Crackers }^{*}\end{array}$} & \multirow{2}{*}{$\begin{array}{l}\text { Crackers } \\
\text { Acuan** }\end{array}$} \\
\hline & F0 & F1 & F2 & F3 & & \\
\hline Air (\%) & $6,88 \pm 0,707^{a}$ & $8,48 \pm 1,1753^{\mathrm{ab}}$ & $10,41 \pm 0,353^{b}$ & $7,99 \pm 1,551^{\mathrm{ab}}$ & Maks 5 & 3,94 \\
\hline $\mathrm{Abu}(\%)$ & $1,83 \pm 0,346^{a}$ & $2,11 \pm 0,254^{a}$ & $2,31 \pm 0,1555^{a}$ & $2,43 \pm 0,205^{a}$ & - & 2,61 \\
\hline Karbohidrat (\%) & $54,61 \pm 0,933^{a}$ & $52,195 \pm 2,538^{a b}$ & $48,45 \pm 2,969^{b}$ & $51,61 \pm 0,565^{a b}$ & - & 62,68 \\
\hline Lemak Total (\%) & $28,68 \pm 0,247^{a}$ & $28,34 \pm 1,237^{a}$ & $29,12 \pm 2,481^{a}$ & $26,9 \pm 1,329^{a}$ & - & 19,95 \\
\hline Protein (\%) & $7,99 \pm 0,268^{a}$ & $8,87 \pm 0,197^{b}$ & $9,7 \pm 0,021^{\mathrm{c}}$ & $11,06 \pm 0,219^{d}$ & $\operatorname{Min} 5$ & 10,83 \\
\hline
\end{tabular}

${ }^{*}$ SNI crackers / biskuit 2973:2011

${ }^{* *}$ Crackers acuan mengacu pada Seftiono et al (2019)

Keterangan: $a, b, c$, dan $d=$ angka-angka pada baris yang sama kemudian diikuti oleh notasi huruf yang sama berarti tidak berbeda nyata pada taraf uji Duncan memiliki nilai 5\%.

tiap sampel tidak terlalu berbeda, jenis protein yang digunakan sama, serta suhu pengolahan yang sama. Faktor-faktor yang mempengaruhi tekstur adalah perbandingan protein-lemak, jenis protein dan suhu pengolahan (Nugrahani, 2014).

Tekstur crackers yang dihasilkan pada penelitian adalah mudah patah. Semakin banyak penambahan tepung kacang bambara maka akan semakin mudah patah. Hal ini dikarenakan adanya penambahan tepung kacang bambara yang semakin banyak, menurut Yildiz dan Bulut, 2015 dalam Istinganah, 2017 kekerasan kue menurun seiring dengan penambahan tepung, hal itu dapat terjadi karena semakin banyak penambahan tepung dibanding bahan lain akan membuat adonan tidak menyatu dengan sempurna sehingga ketika adonan di panggang akan mudah patah.

\section{Rasa}

Penambahan tepung kacang bambara tidak memiliki pengaruh nyata $(p=0,066)$ terhadap tingkat kesukaan panelis pada parameter rasa crackers hal ini disebabkan karena bekatul jagung ditambahkan dengan persentase lebih banyak sehingga memiliki rasa yang dominan dan juga penambahan bekatul jagung dalam produk dapat menurunkan penilaian rasa dan mouthfeel suatu produk (Rose et al., 2010). Menurut Lestari et al., 2018 untuk mengurangi rasa pahit, langu atau tengik pada bekatul dapat dilakukan penyangraian.

\section{Kadar Air}

Hasil sidik ragam menunjukan bahwa penambahan tepung kacang bambara pada crackers bekatul jagung tidak berpengaruh nyata $(p=0,088)$ terhadap kadar air crackers. Crackers F2 memiliki kandungan air tertinggi ini disebabkan crackers F2 matang 5 menit lebih cepat dibandingkan F0, F1 dan F3. Oleh sebab itu F2 memiliki kandungan air tertinggi. Hal ini terjadi karena semakin lama waktu pemanggangan akan mengakibatkan penguapan air dari adonan akan semakin besar (Ketaren, 2005 dalam Sitoresmi, 2012). 
Kadar air pada crackers yang diteliti cukup tinggi. Hal ini disebabkan pada proses pembuatan crackers dilakukan perlakuan perendaman selama 24 jam. Terjadi peningkatan kadar air 0,2 g/100 g kacang bambara yang sebelumnya 10,2 g/100 g menjadi $10,4 \mathrm{~g} / 100 \mathrm{~g}$ setelah dilakukan perendaman selama 24 jam (Okudu \& Ojinnaka, 2017). Selain itu kandungan air bekatul jagung juga tinggi yaitu $4,71 \mathrm{~g} / 100 \mathrm{~g}$ (USDA, 2019).

\section{Kadar Abu}

Penambahan tepung kacang bambara pada crackers bekatul jagung tidak berpengaruh nyata $(p=0,233)$ terhadap kadar abu crackers..

Kadar abu dalam produk pangan sangat berhubungan dengan kadar mineral atau zat anorganik sisa pembakaran yang terdapat dalam suatu produk pangan, ini berkaitan dengan kemurnian serta kebersihan suatu produk yang dihasilkan (Najih \& Nurhidajah, 2011). Jenis mineral yang terkandung dalam kacang bambara adalah kalium, magnesium, fosfor dan zat besi (Amarteifio et al., 2006).

\section{Kadar Karbohidrat}

Hasil uji statistik menunjukkan bahwa penambahan tepung kacang bambara pada crackers bekatul jagung tidak berpengaruh nyata $(p=0,150)$ terhadap kadar karbohidrat crackers.

Penurunan kadar karbohidrat tepung kacang bambara disebabkan oleh bahanbahan yang direndam biasanya akan mengembang dan bersifat semi permiabel, sehingga molekul - molekul senyawa organik seperti gula dan asam amino dengan bebas dapat menembus dinding sel masuk kedalam air (Zahiroh, 2016). Selain itu Kadar karbohidrat sangat dipengaruhi oleh faktor kandungan gizi lainnya. Jika rata-rata kandungan gizi air, abu, protein, dan lemak meningkat, maka nilai karbohidrat menurun dan begitu juga sebaliknya apabila kandungan air, abu, protein, dan lemak menurun, maka akan mengakibatkan nilai karbohidrat meningkat (Thaha et al., 2018)

\section{Kadar Lemak}

Penambahan tepung kacang bambara pada crackers bekatul jagung tidak berpengaruh nyata $(p=0,563)$ terhadap kadar lemak crackers. Crackers F2 mengandung kadar lemak tertinggi, ini dikarenakan crackers F2 matang lebih cepat 5 menit dibanding F0, F1 dan F3. Hal ini disebabkan karena tingkat kerusakan lemak sangat bervariasi tergantung pada suhu yang digunakan dan lamanya waktu proses pengolahan. Makin lama waktu pengolahan, maka semakin intens kerusakan lemak (Sundari, 2015). Saat proses pemasakan yang akan memecah komponen lemak menjadi produk volatil seperti keton, aldehid, asam, alkohol dan hidrokarbon, komponen volatil sangat mempengaruhi pembentukan flavor sehingga semakin lama waktu pemanggangan kadar lemak menjadi lebih rendah (Sitoresmi, 2012).

\section{Kadar Protein}

Terdapat pengaruh nyata $(p=0,000)$ penambahan tepung kacang bambara terhadap kadar protein crackers. Semakin tinggi penambahan tepung kacang bambara maka semakin tinggi kadar protein crackers. Crackers F0 memiliki kadar protein terendah sedangkan crackers F3 memiliki kadar protein tertinggi. Hal ini dikarenakan menurut TKPI (2019) kacang bambara memiliki nilai protein sebesar 16,0 g/100 g BDD yang mana lebih tinggi jika dibandingkan dengan kadar protein tepung terigu $(9,0 \mathrm{~g} / 100 \mathrm{~g}$ BDD) sehingga mengakibatkan penambahan kandungan protein pada produk.

Hasil ini sesuai dengan yang diharapkan peneliti. Kacang bambara merupakan kacang-kacangan sedangkan tepung (gandum) merupakan serealia. Kacangkacangan secara alami mengandung lebih banyak protein daripada serealia meskipun protein yang lazim dalam gandum sering digunakan sebagai gluten yang dibutuhkan dalam pembuatan kue (Adegbanke, Ojo-uyi, et al., 2019). 
Tabel 3. Kandungan Serat Pangan Crackers Bekatul Jagung dengan Penambahan Tepung Kacang Bambara

\begin{tabular}{|c|c|c|c|c|c|c|}
\hline \multirow{2}{*}{ Komponen } & \multicolumn{4}{|c|}{ Sampel } & \multirow{2}{*}{$\begin{array}{c}\text { SNI } \\
\text { Crackers }\end{array}$} & \multirow{2}{*}{$\begin{array}{l}\text { Crackers } \\
\text { Acuan }^{\star *}\end{array}$} \\
\hline & F0 & F1 & F2 & F3 & & \\
\hline Serat Pangan (\%) & $12,98 \pm 0,056^{a}$ & $15,92 \pm 0,36^{b}$ & $20,2 \pm 0,311^{c}$ & $21,17 \pm 0,021^{d}$ & - & 7,14 \\
\hline
\end{tabular}

\section{Analisis Kadar Serat Pangan}

Pada penelitian ini crackers F0 memiliki kadar serat pangan sebesar $12,98 \%$ sedangkan crackers dengan penambahan tepung kacang bambara F1 sebesar 15,92\%, F2 sebesar 20,2\%, dan F3 sebesar $21,17 \%$. Crackers F0 memiliki kadar serat pangan terendah sedangkan crackers F3 memiliki kadar serat pangan tertinggi. Hasil sidik ragam menunjukkan bahwa penambahan tepung kacang bambara berpengaruh nyata $(p=0,000)$ terhadap kadar serat pangan crackers. Semakin tinggi penambahan tepung kacang bambara maka semakin tinggi kadar serat pangan crackers.

Hasil penelitian ini sejalan dengan hasil penelitian Abu-Salem dan Abou-Arab, 2011 yang memiliki hasil kadar serat pangan semakin tinggi seiring dengan semakin banyak penambahan tepung kacang bambara. Menurut TKPI 2019 kadar serat pangan tepung terigu sebesar $0,3 \mathrm{~g} / 100 \mathrm{~g}$ BDD lebih rendah daripada kacang bogor yang sudah dikeringkan (26,3 g/100 $\mathrm{g}$ BDD). Kandungan serat bekatul jagung juga sangat tinggi $79 \mathrm{~g} / 100 \mathrm{~g}$ BDD (USDA, 2019).

\section{KESIMPULAN}

Berdasarkan hasil dan pembahasan dapat ditarik kesimpulan bahwa crackers bekatul jagung dengan penambahan tepung kacang bambara memiliki pengaruh nyata $(p=0,001)$ terhadap tingkat kesukaan panelis pada parameter warna crackers. Semakin tinggi tingkat penambahan tepung kacang bambara maka akan semakin gelap warna crackers.

Pada aspek nilai gizi, penambahan tepung kacang bambara berpengaruhnyata $(p=0,000)$ terhadap kadar protein. Semakin tinggi penambahan tepung kacang bambara maka akan semakin tinggi kadar protein crackers. Selain pada protein penambahan tepung kacang Bambara juga berpenagruh nyata $(p=0,000)$ terhadap kadar serat pangan. Semakin tinggi penambahan tepung kacang bambara maka akan semakin tinggi serat pangan crackers.

Crackers F3 dengan tingkat perbandingan tepung terigu dengan kacang bambara 60:40\% menunjukkan nilai tingkat kesukaan aroma dan tekstur tertinggi serta kadar serat pangan tertinggi namun kadar lemak terendah. Crackers F3 mendapatkan nilai total skor terendah sehingga crackers F3 merupakan formula terpilih yang diharapkan dalam penelitian ini.

\section{DAFTAR PUSTAKA}

Abdualrahman, M. A. Y. et al. (2012) 'Effect of bambara groundnut flour (Vigna subterranea (L.) verde.) supplementation on chemical, physical, nutritional and sensory evaluation of wheat bread', Pakistan Journal of Biological Sciences, 15(17), pp. 845-849. doi: 10.3923/pjbs.2012.845.849.

Adegbanke, O. ., Ojo-uyi, D. . and Oluwajuyitan, T. . (2019) 'Application of Bambara Groundnut in the Production of Cookies', Food Science and Quality Management, 83(January), pp. 56-60. doi: 10.7176/fsqm/83-07.

Dapčević-Hadnađev, T., Hadnađev, M. and Pojić, M. (2018) 'The Healthy Components of Cereal By-Products and Their Functional Properties', in Galanakis, C. M. (ed.) Sustainable Recovery and Reutilization of Cereal 
Processing By-Products. Woodhead Publishing, pp. 27-61. doi: https://doi.org/10.1016/C2016-0-038834.

Dhingra, D. et al. (2012) 'Dietary fibre in foods: A review', Journal of Food Science and Technology, 49(3), pp. 255-266. doi: 10.1007/s13197-011-0365-5.

Fatmawati, I., Pradhan, A. W. and Arini, F. A. (2020) 'The Association Between FastFood Consumption and Physical Activity with Overweight Occurrence at School Among 9-11-Year-Old Children in Cakung Payangan Bekasi', Jurnal IImu Kesehatan Masyarakat, 11(3), pp. 237247. doi: 10.26553/jikm.2020.11.3.236246.

Kementerian Kesehatan Republik Indonesia (2018) 'Hasil Utama Riset Kesehata Dasar (RISKESDAS)', 44(8), pp. 1-200. doi: 10.1088/1751-8113/44/8/085201.

Kementerian Kesehatan Republik Indonesia (2018b) 'KEPUTUSAN MENTERI KESEHATAN REPUBLIK INDONESIA NOMOR HK.01.07/MENKES/406/2018 TENTANG PEDOMAN NASIONAL PELAYANAN KEDOKTERAN TATA LAKSANA KANKER KOLOREKTAL', 11(11), pp. 45-55.

Kementerian Kesehatan Republik Indonesia (2018) 'Tabel Komposisi Pangan Indonesia', Jakarta, Kementerian Kesehatan RI

Kementerian Pertanian (2018) 'Statistik Konsumsi Pangan Tahun 2018', Statistik Konsumsi Pangan, pp. 1-103.

Kusharto, C. M. (2007) 'Serat Makanan Dan Perannya Bagi Kesehatan', Jurnal Gizi dan Pangan, 1(2), p. 45 . doi: 10.25182/jgp.2006.1.2.45-54.

Maryusman, T. et al. (2018) 'Pengaruh Kombinasi Diet Tinggi Serat dan Senam Aerobik terhadap Penurunan Berat
Badan', Jurnal Kedokteran dan Kesehatan, 14(1), p. 56. doi: 10.24853/jkk.14.1.56-62.

$\mathrm{MI}, \mathrm{Y}$. and DD, E. (2018) 'Production of Bambara Groundnut Substituted Whole Wheat Bread: Functional Properties and Quality Characteristics', Journal of Nutrition \& Food Sciences, 08(05). doi: 10.4172/2155-9600.1000731.

Murevanhema, Y. Y. and Jideani, V. A. (2013) 'Potential of Bambara Groundnut ( Vigna subterranea ( L .) Verdc) Milk as a Probiotic Beverage - A Review Potential of Bambara Groundnut ( Vigna subterranea ( $L$.) Verdc ) Milk as a Probiotic Beverage - A Review', (June), pp. 37-41. doi: 10.1080/10408398.2011.574803.

Olagunju, A. I. et al. (2018) 'Development of value-added nutritious crackers with high antidiabetic properties from blends of Acha (Digitaria exilis) and blanched Pigeon pea (Cajanus cajan)', Food Science and Nutrition, 6(7), pp. 17911802. doi: $10.1002 / f s n 3.748$.

Parate, V., Kale, S. and Talib, M. I. (2019) 'Development of Fibre Rich Biscuits from Corn Bran Page No: 1116', IX(I), pp. 1116-1121.

Portal Statistik Perdagangan, viewed 2 September 2021

Rahayu, W. E., Destiana, I. D. and Fathurohman, F. (2020) 'Utilization of Bambara Bean ( Vigna subterranea L .) Flour As a Substitution of Wheat Flour in Making Cookies', 4, pp. 156-161.

Rahmah, A., rezal, F. and rasma, R. (2017) 'Perilaku Konsumsi Serat Pada Mahasiswa Angkatan 2013 Fakultas Kesehatan Masyarakat Universitas Halu Oleo Tahun 2017', Jurnal IImiah Mahasiswa Kesehatan Masyarakat Unsyiah, 2(6), p. 198088. 
ramadhani, kurnia A. (2017) 'PERTUMBUHAN DAN HASIL KACANG BOGOR (Vigna subterranea (L.) Verdc.) VARIETAS LOKAL LEMBANG DI KALIMANTAN SELATAN (Growth', Journal of Chemical Information and Modeling, 53(9), pp. 1689-1699. doi: 10.1017/CBO9781107415324.004.

Rantika, N. and Rusdiana, T. (2018) 'Artikel Tinjauan: Penggunaan Dan Pengembangan Dietary Fiber', Farmaka, 16, pp. 152-165.

Santoso, A. (2011) 'SERAT PANGAN (DIETARY FIBER) DAN MANFAATNYA BAGI KESEHATAN', Magistra, 23, pp. 35-40. doi: 10.1108/eb050265.

Setyowati, W. T. and Nisa, F. C. (2014) 'FORMULASI BISKUIT TINGGI SERAT'
KAJIAN PROPORSI BEKATUL JAGUNG: TEPUNG TERIGU DAN PENAMBAHAN BAKING POWDER ) High-Fiber Biscuit Formulations ( Study of The Proportions of Corn Bran: Wheat Flour and Addition of Baking Powder )', 2(3), pp. 224-231.

Singh, M., Liu, S. X. and Vaughn, S. F. (2012) 'Effect of corn bran as dietary fiber addition on baking and sensory quality', Biocatalysis and Agricultural Biotechnology. Elsevier, 1(4), pp. 348352. doi: 10.1016/j.bcab.2012.02.005.

U.S. Department Of Agriculture. (2019). Fooddata Central. U.S. Department Of Agriculture. Https://Fdc.Nal.Usda.Gov/ 